\title{
Mesalazine to Treat Symptomatic Uncomplicated Diverticular Disease and to Prevent Acute Diverticulitis Occurrence. A Systematic Review with Meta-Analysis of Randomized, Placebo- Controlled Trials
}

\author{
1) Division of Surgery, \\ "P. Colombo" Hospital, \\ ASL Roma 6, Velletri (Rome) \\ 2) Division of \\ Gastroenterology, ASL Roma \\ 6, Albano Laziale (Rome) \\ 3) Gastroenterology Service, \\ ASL BAT, Andria (BT), \\ Italy
}

Marcello Picchio ${ }^{1}$, Walter Elisei ${ }^{2}$, Antonio Tursi ${ }^{3}$

\footnotetext{
Address for correspondence: Antonio Tursi, MD Servizio di Gastroenterologia Territoriale

Via Torino, 49

76123 Andria, Italy antotursi@tiscali.it
}

\begin{abstract}
Background \& Aims: Symptomatic Uncomplicated Diverticular disease (SUDD) affects about 25\% of patients harboring colonic diverticula. We assessed the effectiveness of mesalazine in improving symptoms (namely abdominal pain, primary outcome) and in preventing diverticulitis occurrence (secondary outcome) in patients with SUDD.

Methods: Pertinent studies were selected from the Medline and the Cochrane Central Register of Controlled Trials. Only randomized clinical trials (RCTs) (irrespective of language, blinding, or publication status), which compared mesalazine, irrespective of the dosage assumption, with placebo in SUDD were evaluated. Results: Four RCTs enrolled 379 patients, 197 treated with mesalazine and 182 with placebo. Two studies provided data on symptom relief according to definition: it was achieved in 97/121 (80\%) patients in the mesalazine group and in $81 / 129(62.7 \%)$ patients in the placebo group (OR 0.43; 95\% CI 0.24-0.75; p=0.003 in favour of the mesalazine group). Two studies provided information regarding occurrence of diverticulitis during follow-up. It occurred in $23 / 119$ (19.3\%) patients in the mesalazine group and in $34 / 102(33.3 \%)$ patients in the placebo group (OR 0.35; 95\% CI 0.17-0.70; $\mathrm{p}=0.003$ in favour of the mesalazine group). Conclusions: Treatment with mesalazine seems to be effective in achieving symptom relief and in the primary prevention of diverticulitis in patients with SUDD.
\end{abstract}

Key words: controlled trials - diverticular disease - diverticulitis - mesalazine - meta-analysis - placebo.

Abbreviations: PRISMA: Preferred Reporting Items for Systematic Reviews and Meta-analyses Statement; RCT: Randomized Controlled Trials; SUDD: Symptomatic Uncomplicated Diverticular Disease.

\section{INTRODUCTION}

Diverticulosis of the colon is the most important anatomical alteration detected during colonoscopy in the Western world (1). Its prevalence is increasing with age, affecting almost $50 \%$ of people by the fifth decade (1). About one fifth of those patients will develop symptoms, the so called "diverticular disease" [1, 2]. Currently, there is a growing body of knowledge about the epidemiologic/pathophysiologic pattern of the disease [2]. Overall, annual age-adjusted admissions for acute diverticulitis are strikingly increasing. For example, in the United States population, a $26 \%$ increase between 1998 and 2005 was recorded [3]. Rates of admission increased more rapidly within patients aged $18-44$ years $(+82 \%)$ and 45-74 years ( $+36 \%)$. Elective operations for diverticulitis rose from 16,100 to 22,500 per year during the same time period $(+29 \%)$, also with a more rapid increase $(+73 \%)$ in the rates of surgery for individuals aged 18-44 years [3].

As stated, about one fifth/one fourth of them will develop the "diverticular disease". This can be classified into symptomatic uncomplicated disease (SUDD), recurrent symptomatic disease or complicated disease $[4,5]$.

Symptomatic uncomplicated disease is characterized by abdominal pain (mainly located in the left lower abdominal quadrant) and altered bowel habits $[4,5]$. Among patients with diverticular disease, it is thought that $25 \%$ develop complications, $1-2 \%$ require hospitalisation and $0.5 \%$ surgery $[3,6]$. However, a recent endoscopy-based study found a lower rate $(5 \%)$ of diverticulitis at a 5 -year follow-up in diverticulosisproven patients [7]. On the contrary, recurrence of acute 
diverticulitis was reported to be higher, involving up to $20 \%$ of patients following the first episode [8].

Although the diagnosis of diverticular disease can be relatively straightforward, randomized controlled trials about clinical management are scarce and it often follows tradition rather than principles of evidence-based medicine. Some practice guidelines do exist, but the majority of them are relatively old and rely on expert opinions mainly.

Current guidelines recommend only the use of fibres and spasmolytics in treating SUDD [9]. Recent studies showed a substantial benefit of mesalazine in SUDD with respect to reducing symptoms, maintaining remission in the majority of patients, and preventing diverticulitis occurrence [10-19]. However, an in-depth analysis about the benefit of mesalazine, when compared with placebo, is lacking.

The aim of the present review was to compare the efficacy of mesalazine vs placebo on symptom improvement and occurrence of diverticulitis in patients with SUDD.

\section{METHODS}

The analysis and generation of inclusion criteria were based on the Preferred Reporting Items for Systematic Reviews and Meta-Analyses Statement (PRISMA) recommendations [20].

\section{Types of studies, participants, and interventions}

Randomized clinical trials (irrespective of language, blinding, or publication status), which compared mesalazine, irrespective of the dosage regimen, with placebo in SUDD were evaluated. Any other type of study (randomized but without placebo-controlled control group, cohort studies, case series) as well as case reports were excluded.

\section{Types of outcome measures}

The selected primary outcome was the percentage of patients with symptom relief at maximal follow-up. The secondary outcome was diverticulitis occurrence at maximal follow-up.

\section{Literature search}

The RCTs were identified by searching MEDLINE, and the Cochrane Central Register of Controlled Trials from 1966 to November 2017. A computer-assisted search was conducted using the following combination of medical subject heading terms (MESH and not MESH terms): 'diverticular disease' AND 'mesalazine' AND 'clinical trial. The search strategy for PubMed used the strings: ((„diverticulum”[MeSH Terms] OR „diverticulum”[All Fields] OR („diverticular”[All Fields] AND „disease”[All Fields]) OR „diverticular disease”[All Fields]) AND („mesalamine”[MeSH Terms] OR „mesalamine”[All Fields] OR „mesalazine”[All Fields])) AND Clinical Trial[ptyp]. No language limits were imposed. A search of the abstract books from the British Society of Gastroenterology (2000 November 2017), American Gastroenterological Association (2000-2017), American College of Gastroenterology (2004 - November 2017), United European Gastroenterology Federation (2000 - November 2017) and Asian Pacific Digestive Week (2003 - November 2017), as well as searching of the books of other international congresses on this topic was performed. Bibliographies of all identified relevant studies were used to perform a recursive search. In addition, authors were contacted in order to obtain unpublished data from their studies, whenever deemed necessary.

\section{Data extraction}

All data were extracted independently by two reviewers (AT and MP) using a paper data extraction form. The accuracy of the extracted data was further confirmed by a third author (WE). The information, collected from each study, included: study design, definition of primary and secondary outcomes and frequencies of each end-point.

\section{Assessment of risk of bias}

Two raters (AT and MP) independently assessed the methodological quality of the included studies according to the Cochrane Collaboration guidelines [21]. A third investigator (WE) arbitrated in the event of a lack of agreement.

\section{Statistical analysis}

We performed the analysis using the software package Review Manager Version 5.3.5 software (Cochrane Collaboration). For dichotomous variables, we calculated the odds ratio (OR) with $95 \%$ confidence interval (CI). We used the Mantel-Haenszel method to calculate the weighted summary OR. Heterogeneity was assessed by the $\mathrm{I}^{2}$ measure of inconsistency, statistically significant if $\mathrm{I}^{2}$ was $>50 \%$; whenever $\mathrm{I}^{2}$ was $<50 \%$, the fixed-effects model results were used; otherwise, the random-effects model results were preferred. For all the outcomes a $\mathrm{P}$ value of less than 0.05 was considered statistically significant.

\section{RESULTS}

Figure 1 illustrates the PRISMA flow chart for study inclusion and exclusion. The database search retrieved 68 records. Four further records were identified in the reference lists. After deleting duplicate results, a total of 66 records remained for title and abstract review. Of these, 10 trials were selected for full-text examination. Three studies were excluded because patients were not randomized $[10,16,17]$. Three studies were excluded because no placebo-control group was present [13-15]. Four studies fulfilled the inclusion criteria and were suitable for the analysis $[18,19,22,23]$.

\section{Characteristics of the included studies}

Two double-blind, placebo-controlled randomised trials have been published as full papers. Two further double-blind, placebo-controlled randomised trials have been published as abstracts. The characteristics of the studies are reported in Table I.

\section{Analysis of data}

Three studies provided data on symptom relief according to definition: it was achieved in 97 out of $121(80 \%)$ patients in the mesalazine group and in 81 out of $129(62.7 \%)$ patients in the placebo group. Pooled analysis showed statistically significant difference in favour of the mesalazine group (OR 0.43; 95\% CI $0.24-0.75 ; \mathrm{p}=0.003$; Fig. 2). Heterogeneity was not statistically significant $\left(\mathrm{I}^{2}=65 \%, \mathrm{p}=0.06\right)$. 


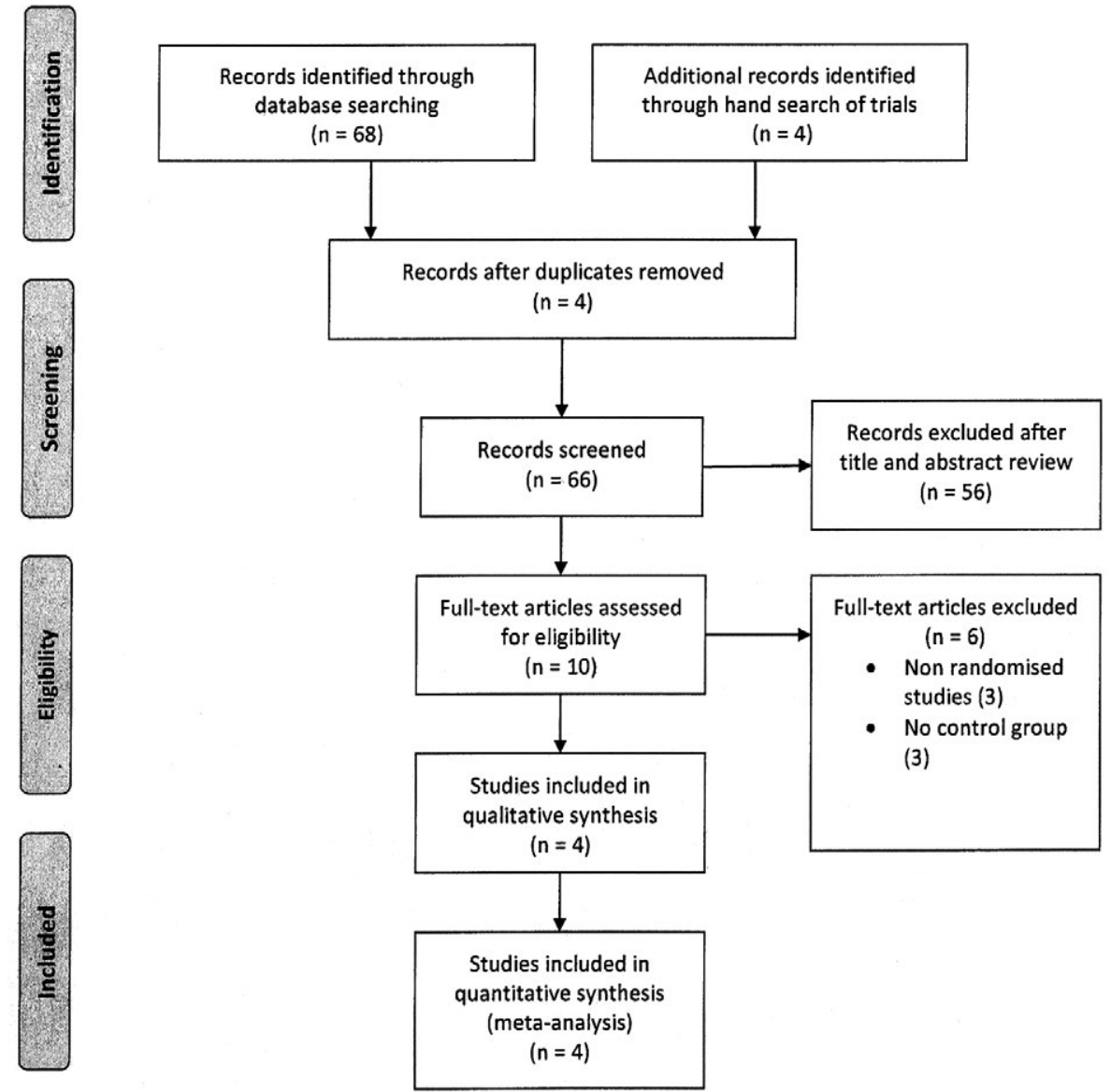

Fig. 1. Article identification and selection algorithm.

Two studies provided information about the occurrence of diverticulitis during follow-up. Acute diverticulitis in SUDD occurred in 23 out of 119 (19.3\%) patients in the mesalazine group and in 34 out of $102(33.3 \%)$ patients in the placebo group. Pooled analysis showed statistically significant difference in favour of the mesalazine group (OR 0.35; 95\% CI 0.17-0.70; $p=0.003$; Fig. 3). Heterogeneity was not statistically significant $\left(\mathrm{I}^{2}=38 \%, \mathrm{p}=0.20\right)$.

\section{Risk of bias}

The Cochrane Collaboration's tool for assessing risk of bias is shown in Fig. 4. As expected, only the two full-paper trials $[18,19]$ were of high quality.

\section{DISCUSSION}

Most patients with colonic diverticulosis do not report any gastrointestinal symptoms during their lifespan and only about $20-25 \%$ of them complain of symptoms [2]. Despite this low percentage, it is clear that a lot of people will suffer from symptoms related to diverticula, since diverticulosis affects a vast majority of over-50-year people.

Symptomatic uncomplicated disease is the most common clinical form of symptomatic diverticular disease, and the left lower quadrant pain is the best symptom characterizing it, able to differentiate it from pain occurring in the irritable bowel syndrome $[24,25]$.
The standard treatment to relieve symptoms and to prevent diverticulitis occurrence in those patients is still under debate. Consistent evidence indicates that dietary fibres, especially the insoluble fibres found mostly in fruits and vegetables rather than cereals, decrease the risk of diverticula development, but evidence with respect to SUDD and diverticulitis is still lacking $[26,27]$. A recent systematic review assessed the role of fibres in those patients [27]. It reported studies of low quality, and authors concluded that high-quality evidence for a high-fibre diet in the treatment of SUDD and in preventing diverticular disease complications (namely diverticulitis) is lacking, and most recommendations are based on inconsistent level 2 and mostly level 3 evidence.

The administration of the non-absorbable antibiotic rifaximin is another option in those people. A meta-analysis assessed the long-term efficacy of rifaximin in patients with SUDD, analyzing four randomised, prospective studies (one of low quality, two of medium quality and one of good quality) [28]. Authors found rifaximin able to reduce most of the clinical manifestations of diverticular disease and, when compared with fibre supplementation alone, it was reported to improve the clinical benefits of dietary fibres in SUDD [28]. However, if we consider the only good quality RCT, which was a double-blind, randomised, placebo-controlled study, we can notice that no difference was found between the rifaximin and placebo group with respect to diverticulitis occurrence [29]. 
Table I. Summary of characteristics of the included studies.

\begin{tabular}{|c|c|c|c|c|c|}
\hline Study [reference] & Methods & Participants & Interventions & Outcomes & Notes \\
\hline Gaman 2011 [22] & $\begin{array}{l}\text { Randomisation: true. } \\
\text { Blind outcome } \\
\text { assessment: not } \\
\text { reported. } \\
\text { Follow up: } 40.47 \pm \\
1.28 \text { months. } \\
\text { Withdrawal: } 0 \%\end{array}$ & $\begin{array}{l}\text { males and females; } \\
\text { diverticulosis showed } \\
\text { by colonoscopy at } \\
\text { study entry }\end{array}$ & $\begin{array}{l}\text { Group M: } 514.7 \pm 30.5 \mathrm{mg} \\
\text { mesalazine/day (68 pts) } \\
\text { Group P: placebo (52 pts). }\end{array}$ & $\begin{array}{l}\text { Study parameters were } \\
\text { occurrence of diverticulitis, } \\
\text { time to first flare, number } \\
\text { of flares and need for } \\
\text { surgery. }\end{array}$ & $\begin{array}{l}\text { We failed in contacting } \\
\text { authors of this study, } \\
\text { and no further } \\
\text { information were } \\
\text { recorded. }\end{array}$ \\
\hline Kruis 2013 [18] & $\begin{array}{l}\text { Randomisation: true. } \\
\text { Blind outcome } \\
\text { assessment: no. } \\
\text { Follow up: } 1 \text { year. } \\
\text { Withdrawal: } 0 \% \text {. } \\
\text { Fourteen centres. }\end{array}$ & $\begin{array}{l}\text { age } 45-80 \text { years; } \\
\text { diagnosis of } \\
\text { diverticular disease } \\
\text { with acute pain } \\
\text { without serious } \\
\text { complications }\end{array}$ & $\begin{array}{l}\text { Group M: mesalazine } 1000 \\
\text { mg t.d.s for } 6 \text { weeks. } \\
\text { Group P: placebo } 1000 \mathrm{mg} \\
\text { t.d.s. for } 6 \text { weeks. }\end{array}$ & $\begin{array}{l}\text { The primary endpoint was } \\
\text { the change in intensity } \\
\text { of lower abdominal pain } \\
\text { during the first } 4 \text { weeks of } \\
\text { treatment. } \\
\text { Other secondary endpoints } \\
\text { included the number of } \\
\text { patients with complete } \\
\text { pain relief and the median } \\
\text { time to complete pain } \\
\text { relief based on patient } \\
\text { diary entries, the change } \\
\text { in the combined symptom } \\
\text { score (at week } 4 \text { and week } \\
\text { 6), the number of patients } \\
\text { requiring spasmolytics, and } \\
\text { analgesics, and the global } \\
\text { assessment of efficacy as } \\
\text { assessed by the patient and } \\
\text { investigator. }\end{array}$ & $\begin{array}{l}\text { The first double blind, } \\
\text { placebo-controlled } \\
\text { study assessing the } \\
\text { effectiveness of } \\
\text { mesalazine in treating } \\
\text { SUDD, defined as } \\
\text { diverticulosis with } \\
\text { lower abdominal pain } \\
\text { of moderate or severe } \\
\text { intensity on at least } 4 \\
\text { of the previous } 7 \text { days } \\
\text { before study inclusion, } \\
\text { without serious } \\
\text { complications (e.g. } \\
\text { peritonitis, abscess, } \\
\text { fistula, visible blood on } \\
\text { stool not originating } \\
\text { from hemorrhoids, } \\
\text { ileus, stenosis). }\end{array}$ \\
\hline Tursi 2013 [19] & $\begin{array}{l}\text { Randomisation: true. } \\
\text { Blind outcome } \\
\text { assessment: yes. } \\
\text { Follow up: } 1 \text { year. } \\
\text { Withdrawal: } 0 \% \text {. } \\
\text { Fourteen centres }\end{array}$ & $\begin{array}{l}\text { males and females } \\
\text { aged }>18 \text { years; } \\
\text { diverticulosis showed } \\
\text { by colonoscopy no } \\
\text { more than } 6 \text { months } \\
\text { prior to study entry; } \\
\text { symptomatic episode } \\
\text { of uncomplicated } \\
\text { diverticular disease } \\
\text { no more than } 4 \text { weeks } \\
\text { prior to study entry. }\end{array}$ & $\begin{array}{l}\text { Group M: Active } \\
\text { Mesalazine, } 2 \text { tablets } 800 \\
\text { mg/day for } 10 \text { days/month } \\
\text { plus Lactobacillus casei } \\
\text { placebo, } 1 \text { sachet/day for } \\
10 \text { days/month; } \\
\text { Group L: Active } \\
\text { Lactobacillus casei, } 1 \\
\text { sachet/day for } 10 \text { days/ } \\
\text { month plus Mesalazine } \\
\text { placebo, } 2 \text { tablets/day for } \\
10 \text { days/month; } \\
\text { Group LM: Active } \\
\text { Mesalazine, } 2 \text { tablets } \\
800 \text { mg/day plus Active } \\
\text { Lactobacillus casei, } 1 \\
\text { sachet/day for } 10 \text { days/ } \\
\text { month; } \\
\text { Group P: Mesalazine } \\
\text { placebo, } 2 \text { tablets/day and } \\
\text { Lactobacillus casei placebo, } \\
1 \text { sachet/day for } 10 \text { days/ } \\
\text { month. }\end{array}$ & $\begin{array}{l}\text { The primary endpoint was } \\
\text { the proportion of patients } \\
\text { maintaining remission } \\
\text { after a previous episode } \\
\text { of SUDD, defined as the } \\
\text { presence of symptoms } \\
\text { (mainly abdominal pain, } \\
\text { but also constipation, } \\
\text { diarrhoea and bloating) in } \\
\text { patients with diverticulosis, } \\
\text { in the absence of any } \\
\text { complication (stenoses, } \\
\text { abscesses, fistulas), in } \\
\text { whom the presence of } \\
\text { abdominal pain was } \\
\text { recorded in the lower left } \\
\text { quadrant as lasting for } \\
>24 \text { consecutive hours. } \\
\text { Maintenance of remission } \\
\text { was defined as absence } \\
\text { of recurring abdominal } \\
\text { pain scored } \geq 5 \text { for at least } \\
24 \text { consecutive hours and } \\
\text { recorded at any time during } \\
\text { the follow-up). }\end{array}$ & $\begin{array}{l}\text { Group } M \text { and Group } \\
\text { P were included in the } \\
\text { current meta-analysis. }\end{array}$ \\
\hline Smith 2012 [23] & $\begin{array}{l}\text { Randomisation: true. } \\
\text { Blind outcome } \\
\text { assessment: not } \\
\text { reported. } \\
\text { Follow-up: } 3 \\
\text { months. } \\
\text { Withdrawal: } 11 / 45 \\
\text { (25.6\%). }\end{array}$ & $\begin{array}{l}\text { males and females; } \\
\text { symptomatic episode } \\
\text { of diverticular } \\
\text { disease (no definition } \\
\text { provided) at study } \\
\text { entry; } \\
\text { unprepared flexible } \\
\text { sigmoidoscopy and } \\
\text { biopsies at baseline } \\
\text { and after } 12 \text { weeks } \\
\text { treatment }\end{array}$ & $\begin{array}{l}\text { Group M: } 3 \mathrm{~g} \text { per day of } \\
\text { mesalazine for } 12 \text { weeks } \\
\text { (14 pts). } \\
\text { Group P: } 3 \text { g placebo for } 12 \\
\text { weeks ( } 18 \text { pts) }\end{array}$ & $\begin{array}{l}\text { Gene expression and } \\
\text { changes in duration of } \\
\text { abdominal pain were } \\
\text { assessed between baseline } \\
\text { and final visits (see text for } \\
\text { further information). }\end{array}$ & $\begin{array}{l}\text { Authors were } \\
\text { contacted and provided } \\
\text { information on the } \\
\text { proportion of patients } \\
\text { with reduction in the } \\
\text { duration of abdominal } \\
\text { pain at the end of } \\
\text { follow-up. }\end{array}$ \\
\hline
\end{tabular}

A recent hypothesis underlines the role of inflammation in the pathogenesis of diverticular disease, ranging from increased inflammatory infiltrate to enhanced expression of pro-inflammatory cytokine TNFa [30]. Hence, diverticular disease may be considered as a chronic inflammatory process, in which mesalazine may be an interesting therapeutic tool. 


\begin{tabular}{|c|c|c|c|c|c|c|c|c|c|}
\hline Study or Subgroup & \multicolumn{2}{|c|}{ Mesalazine } & \multicolumn{2}{|c|}{ Placebo } & \multicolumn{2}{|r|}{$\begin{array}{l}\text { Odds Ratio } \\
\text { M-H, Fixed, } 95 \% \mathrm{Cl} \text { Year }\end{array}$} & \multicolumn{3}{|c|}{$\begin{array}{c}\text { Odds Ratio } \\
\text { M-H, Fixed, } 95 \% \mathrm{Cl}\end{array}$} \\
\hline Smith 2013 & 3 & 14 & 8 & 18 & $14.6 \%$ & $0.34[0.07,1.65] 2013$ & & \begin{tabular}{l|l}
$\square$ &
\end{tabular} & \\
\hline Kruis 2013 & 14 & 56 & 17 & 61 & $32.3 \%$ & $0.86[0.38,1.97] 2013$ & & & \\
\hline Tursi 2013 & 7 & 51 & 23 & 50 & $53.1 \%$ & $0.19[0.07,0.49] 2013$ & & 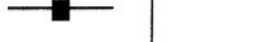 & \\
\hline Total $(95 \% \mathrm{Cl})$ & & 121 & & 129 & $100.0 \%$ & $0.43[0.24,0.75]$ & & & \\
\hline Total events & 24 & & 48 & & & & & & \\
\hline $\begin{array}{l}\text { Heterogeneity: } \mathrm{Ch}^{2}= \\
\text { Test for overall effect: }\end{array}$ & $\begin{array}{l}65, \mathrm{df}=2 \\
=2.95(\mathrm{P}\end{array}$ & $\begin{array}{l}(P=0 . \\
=0.00\end{array}$ & $\begin{array}{l}06) ; 1^{2}=6 \\
\text { 3) }\end{array}$ & & & & 0.01 & 1 & 10 \\
\hline
\end{tabular}

Fig. 2. Forest plot analysing the effect of mesalazine in obtaining symptoms relief.

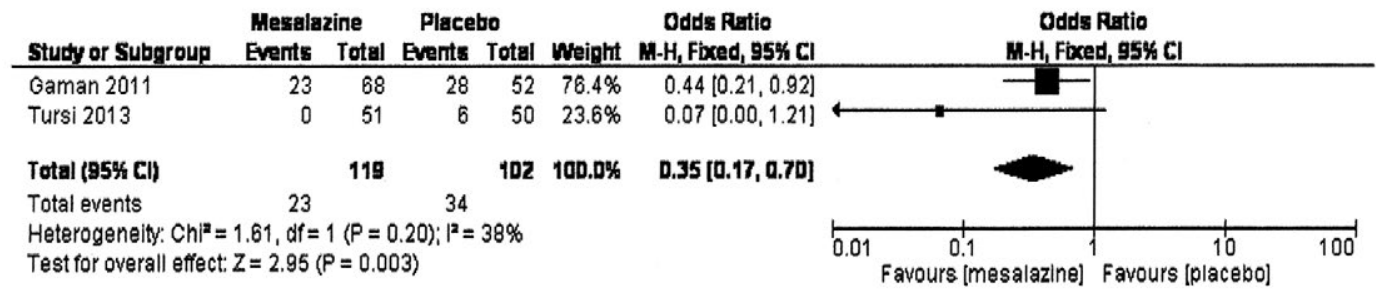

Fig. 3. Forest plot analysing the effect of mesalazine in preventing acute diverticulitis occurrence.

Mesalazine was found to be better than rifaximin in both reducing symptoms and preventing diverticulitis occurrence in SUDD [12, 14]. Although limited by the open-label design, these studies found that mesalazine has a significant advantage over rifaximin in managing those patients.

The purpose of the present meta-analysis was to evaluate the efficacy of the administration of mesalazine vs. placebo on symptom relief and the prevention of occurrence of diverticulitis in patients with SUDD. Overall, it shows that mesalazine is an effective therapeutic tool in SUDD patients, both in relieving symptoms and in preventing diverticulitis occurrence. In particular, two fully published double-blind, placebo-controlled trials found mesalazine better than placebo in controlling symptoms $[18,19]$, and one of them also in

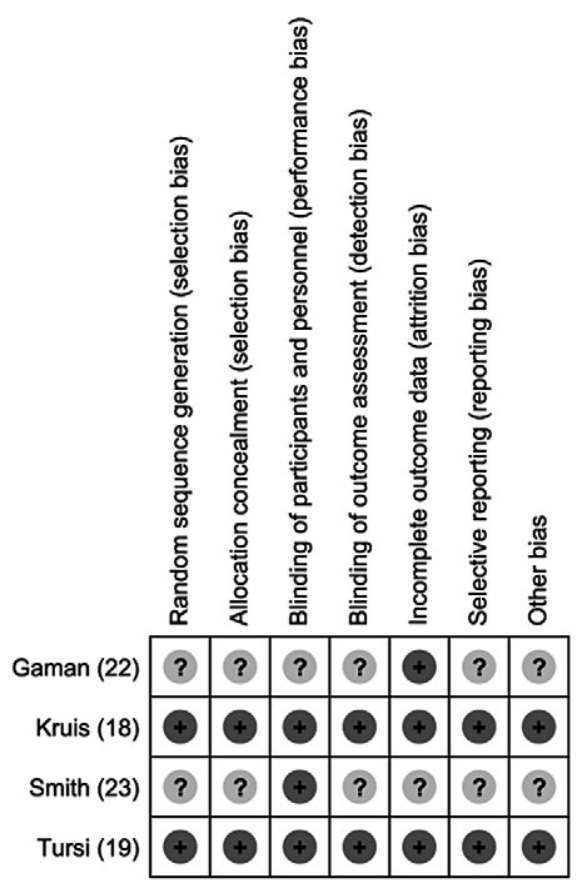

Fig. 4. Risk of bias of the included trials. preventing diverticulitis occurrence in those patients [19]. Another point reinforcing the results of these studies was that, although the definition of SUDD is difficult and without standards, both studies provided a similar definition of this condition $[18,19]$. It is noteworthy that in the trial by Tursi et al. an impressive remission rate was obtained when using the association mesalazine-probiotic (Lactobacillus casei subsp. Paracasei strain).

The possible explanation of this result is that combination of mesalazine and probiotics acts against inflammation in two ways (by inhibition of inflammatory cascade and restoration of colonic microbiota imbalance, inhibiting both colonic bacterial overgrowth and metabolism of pathogens), keeping virtually all patients symptom free.

However, our study has some limitations. First, the number of RCTs included is low. This may be due to the fact that mesalazine is now out of patent and it is unlikely that any large RCT in SUDD could ever be sponsored. We found two further double-blind, randomised, placebo-controlled studies in SUDD patients, published only in abstract form. The first trial was conducted in Romania, and found mesalazine better than placebo in reducing the risk of developing diverticulitis over a 40-month period [22]. Unfortunately, we failed to contact the authors, and the quality of this trial remains poor. The second trial was conducted in the United Kingdom, and authors provided further information. It found that mesalazine was significantly better than placebo in reducing the duration of abdominal pain in SUDD patients, as well as the expression of inflammatory genes expression in sigmoid mucosa [23]. Significantly, this trial assessed also mucosal expression of several inflammatory genes (NOD2, PAR2, IL-1B, TNFa, TLR4, TLR9, MYD88): mesalazine was always found better than placebo in reducing significantly mucosal expression of these inflammatory genes [23]. Unfortunately, both of these trials have been published only in abstract form.

The second limit is the low population enrolled in the selected trials, and this could lead to an overestimation of the treatment effect of mesalazine. 
Another limit is that this study assessed only the effectiveness of mesalazine in patients with SUDD. The role of mesalazine in preventing diverticulitis recurrence was not an endpoint of this study, because SUDD and diverticulitis seem to show different response to medical treatment [30]. In particular, mesalazine seems to be effective in preventing primary diverticulitis occurrence from SUDD but not secondary diverticulitis recurrence $[31,32]$. A potential explanation is that SUDD and diverticulitis are two different diseases. SUDD is characterized by mucosal inflammation, while acute diverticulitis is characterized by transmural inflammation, leading to fibrosis. Fibrosis may be the key point explaining why mesalamine is effective in SUDD but not in diverticulitis [33, 34]. If the patients are at their first episode of diverticulitis, it is probable that the disease has still lower levels of fibrosis and greater inflammation: in those patients, mesalamine is still able to control inflammation and, thus, symptoms and recurrence of the disease. On the contrary, more than two attacks are able to cause fibrosis, limiting the mesalazine absorption across the colonic wall, so that it is ineffective. Another key point is in relation to the potential differences among mesalazine formulations. Indeed, the mechanism of discharging the mesalazine from the proximal to the distal colon (Eudragit $\mathrm{L}$, granules, $\mathrm{MMX}^{\circledR}$ ) might in part explain the differences in the literature for symptom control. Therefore, further studies are needed to overcome the above mentioned limits, for example by enrolling patients with the same endoscopic and/or radiological findings. The first endoscopic classification of diverticular disease of the colon has been recently developed and validated [35]. It is advisable that the future trials will enrol homogeneous populations in order to define a correct therapeutic strategy for this complex disease. Hence, the role of mesalazine in those patients has to be clarified by further studies.

\section{CONCLUSION}

The present analysis confirms that mesalazine is more effective than placebo in obtaining symptom relief and in preventing diverticulitis occurrence in SUDD. We add also that this is the best evidence that could ever be obtained on this topic, since mesalazine is now out of patent and it is unlikely that any large RCT in SUDD could ever be sponsored.

Conflicts of interest: The authors declare that they have no conflicts of interest concerning this article.

\section{Funding: None.}

Authors' contribution: A.T.: conception and design of the study; M.P., W.E., A.T.: acquisition of data, or analysis and interpretation of data, drafting the article or revising it critically for important intellectual content: and final approval of the version to be submitted.

\section{REFERENCES}

1. Tursi A. Diverticulosis today: unfashionable and still underresearched. Therap Adv Gastroenterol 2016;9:213-228. doi:10.1177/1756283X15621228
2. Tursi A, Papa A, Danese S. Review article: the pathophysiology and medical management of diverticulosis and diverticular disease of the colon. Aliment Pharmacol Ther 2015;42:664-684. doi:10.1111/ apt.13322

3. Etzioni DA, Mack TM, Beart RW Jr, Kaiser AM. Diverticulitis in the United States: 1998-2005: changing patterns of disease and treatment. Ann Surg 2009;249:210-217. doi:10.1097/SLA.0b013e3181952888

4. Tursi A, Papagrigoriadis S. Review article: the current and evolving treatment of colonic diverticular disease. Aliment Pharmacol Ther 2009;30:532-546. doi:10.1111/j.1365-2036.2009.04072.x

5. Humes D, Simpson J, Spiller R. Colonic diverticular disease. BMJ Clin Evid 2007;2007:0405.

6. Haglund U, Hellberg R, Johnsén C, Hultén L. Complicated diverticular disease o the sigmoid colon. An analysis of short and long term outcome in 392 patients. Ann Chir Gynaecol 1979;68:41-46.

7. Shahedi K, Fuller G, Bolus R, et al. Long-term risk of acute diverticulitis among patients with incidental diverticulosis found during colonoscopy. Clin Gastroenterol Hepatol 2013;11:1609-1613. doi:10.1016/j. cgh.2013.06.020

8. Binda GA, Arezzo A, Serventi A, et al. Multicentre observational study of the natural history of left-sided acute diverticulitis. Br J Surg 2012;99:276-285. doi:10.1002/bjs.7723

9. World Gastroenterology Organisation (WGO) Practice Guidelines 2007. Diverticular disease. Available at: http://www.worldgastroenterologyorg/ assets/downloads/en/pdf/guidelines/07_diverticular_disease pdf. Accessed 15 April 2008

10. Trespi E, Colla C, Panizza P, et al. Therapeutic and prophylactic role of mesalazine (5-ASA) in symptomatic diverticular disease of the large intestine. 4 year follow-up results. Minerva Gastroenterol Dietol 1999;45:245-252.

11. Brandimarte G, Tursi A. Rifaximin plus mesalazine followed by mesalazine alone is highly effective in obtaining remission of symptomatic uncomplicated diverticular disease. Med Sci Monit 2004;10:PI70-PI73.

12. Di Mario F, Aragona G, Leandro G, et al. Efficacy of mesalazine in the treatment of symptomatic diverticular disease. Dig Dis Sci 2005;50:581586. doi:10.1007/s10620-005-2478-Z

13. Tursi A, Brandimarte G, Giorgetti GM, Elisei W. Mesalazine and/ or Lactobacillus casei in preventing recurrence of symptomatic uncomplicated diverticular disease of the colon: a prospective, randomized, open-label study. J Clin Gastroenterol 2006;40:312-316. doi:10.1097/01.mcg.0000210092.77296.6d

14. Comparato G, Fanigliulo L, Cavallaro LG, et al. Prevention of complications and symptomatic recurrences in diverticular disease with mesalazine: a 12-month follow-up. Dig Dis Sci 2007;52:2934-2941. doi:10.1007/s10620-007-9766-8

15. Tursi A, Brandimarte G, Giorgetti GM, Elisei W. Continuous versus cyclic mesalazine therapy for patients affected by recurrent symptomatic uncomplicated diverticular disease of the colon. Dig Dis Sci 2007;52:671-674. doi:10.1007/s10620-006-9551-0

16. Tursi A, Brandimarte G, Giorgetti GM, Elisei W. Mesalazine and/or Lactobacillus casei in maintaining long-term remission of symptomatic uncomplicated diverticular disease of the colon. Hepatogastroenterology 2008;55:916-920.

17. Gatta L, Di Mario F, Curlo M, et al. Long-term treatment with mesalazine in patients with symptomatic uncomplicated diverticular disease. Intern Emerg Med 2012;7:133-137. doi:10.1007/s11739-011-0509-7

18. Kruis W, Meier E, Schumacher M, et al; German SAG-20 Study Group. Randomised clinical trial: mesalazine (Salofalk granules) for 
uncomplicated diverticular disease of the colon--a placebo-controlled study. Aliment Pharmacol Ther 2013;37:680-690. doi:10.1111/apt.12248

19. Tursi A, Brandimarte G, Elisei W, et al. Randomised clinical trial mesalazine and/or probiotics in maintaining remission of symptomatic uncomplicated diverticular disease--a double-blind, randomised, placebo-controlled study. Aliment Pharmacol Ther 2013;38:741-751. doi:10.1111/apt.12463

20. Liberati A, Altman DG, Tetzlaff J, et al. The PRISMA statement for reporting systematic reviews and meta-analyses of studies that evaluate health care interventions: explanation and elaboration. Ann Intern Med 2009;151:W65-W94. doi:10.7326/0003-4819-151-4-200908180-00136

21. Higgins JPT, Green S. (eds.). Cochrane handbook for Systematic Reviews Of Interventions, version 5.1.0. 2011. The Cochrane Collaboration, 2011. Available at: http://www.cochrane.handbook.org. Accessed May 24, 2014.

22. Gaman A, Teodorescu R, Georhescu EF, Tataru Abagiu M. Prophylactic effects of mesalamine in diverticular disease. Falk Symposium 2011;178:Abstract 13.

23. Smith JK, Humes DJ, Garsed K, et al. OC-119 Mechanistic randomised control trial of mesalazine in symptomatic diverticular disease. Gut 2012;61(Suppl 2):A51-A52. doi:10.1136/gutjnl-2012-302514a.119

24. Cuomo R, Barbara G, Andreozzi P, et al. Symptom patterns can distinguish diverticular disease from irritable bowel syndrome. Eur J Clin Invest 2013;43:1147-1155. doi:10.1111/eci.12152

25. Tursi A, Elisei W, Picchio M, Giorgetti GM, Brandimarte G. Moderate to severe and prolonged left lower-abdominal pain is the best symptom characterizing symptomatic uncomplicated diverticular disease of the colon: a comparison with fecal calprotectin in clinical setting. J Clin Gastroenterol 2015;49:218-221. doi:10.1097/MCG.0000000000000094

26. Peery AF, Barrett PR, Park D, et al. A high-fiber diet does not protect against asymptomatic diverticulosis. Gastroenterology 2012;142:266272.e1. doi:10.1053/j.gastro.2011.10.035
27. Ünlü C, Daniels L, Vrouenraets BC, Boermeester MA. A systematic review of high-fibre dietary therapy in diverticular disease. Int $\mathrm{J}$ Colorectal Dis 2012;27:419-427. doi:10.1007/s00384-011-1308-3

28. Bianchi M, Festa V, Moretti A, et al. Meta-analysis: long-term therapy with rifaximin in the management of uncomplicated diverticular disease. Aliment Pharmacol Ther 2011;33:902-910. doi:10.1111/j.13652036.2011.04606.x

29. Colecchia A, Vestito A, Pasqui F, et al. Efficacy of long term administrration of the poorly absorbed antibiotic rifaximin in symptomatic, uncomplicated colonic diverticular disease. World J Gastroenterol 2007;13:264-269.

30. Tursi A. New physiopathological and therapeutic approaches to diverticular disease: an update. Expert Opin Pharmacother 2014;15:1005-1017. doi:10.1517/14656566.2014.903922

31. Raskin JB, Kamm MA, Jamal MM, et al. Mesalamine Does Not Prevent Recurrent Diverticulitis in Phase 3 Controlled Trials. Gastroenterology 2014;147:793-802. doi:10.1053/j.gastro.2014.07.004

32. Kruis W, Kardalinos V, Eisenbach T, et al. Randomised clinical trial: mesalazine versus placebo in the prevention of diverticulitis recurrence. Aliment Pharmacol Ther 2017;46:282-291. doi:10.1111/apt.14152

33. Tursi A, Elisei W, Giorgetti GM, et al. Expression of basic fibroblastic growth factor, syndecan 1 and tumour necrosis factor $\alpha$ in resected acute colonic diverticulitis. Colorectal Dis 2014;16:O98-103. doi:10.1111/ codi. 12504

34. Tursi A, Elisei W, Inchingolo CD, et al. Chronic diverticulitis and Crohn's disease share the same expression of basic fibroblastic growth factor, syndecan 1 and tumour necrosis factor- $\alpha$. J Clin Pathol 2014;67:844846. doi:10.1136/jclinpath-2013-202137

35. Tursi A, Brandimarte G, Di Mario F, et al. Development and validation of an endoscopic classification of diverticular disease of the colon: the DICA classification. Dig Dis 2015;33:68-76. doi:10.1159/000366039 